\title{
INTERNET ADOPTION OF INDONESIAN REMOTE SOCIETY: INTEGRATED BROADBAND VILLAGE VERSUS COMMERCIAL MOBILE BROADBAND
}

\author{
Darman Fauzan Dhahir \\ Balai Besar Pengembangan SDM dan Penelitian Komunikasi dan Informatika Makassar \\ Jl. Prof. Dr. Abdurrahman Basalamah II No. 25, Makassar, 90321, Indonesia \\ No. Telp./HP: +624114660084 \\ E-mail: darm007@kominfo.go.id
}

Naskah diterima pada tanggal 26 September 2018, direvisi tanggal 17 November 2018, disetujui tanggal 21 November 2018

\section{ADOPSI INTERNET MASYARAKAT TERPENCIL INDONESIA: DESA BROADBAND TERPADU VERSUS LAYANAN BROADBAND KOMERSIL}

\begin{abstract}
A free integrated broadband facility provision by the Indonesian Government in several remote villages seems has not been successfully narrowing down the digital divide. To establish a solution, the gap that caused the problem needs to reveal. Therefore, the current research was conducted with the aim of illustrating the efforts the Indonesian government has made those in term of narrowing down the digital divide, as well as the community feedback in term of how they adopt the internet. Data was obtained from observations and discussions with the government officials and society in several purposive selected rural villages in Eastern Indonesia. It is qualitatively analysed using the diffusion of innovation point of view. The research result gives an overview that the facilities provided by Integrated Broadband Village (IBV) have not been welcomed enthusiasm, whereas the commercial mobile broadband (CMB) network services those are not free was more preferred due to the advantages in all phases of diffusion of innovations. Unfortunately, CMB is not evenly available especially in areas with minimal population. Besides, the efforts of local governments in developing community access are differing in degrees.
\end{abstract}

Keywords: communication, internet adoption, remote society, rural development.

\begin{abstract}
Abstrak. Fasilitas broadband terpadu gratis yang disediakan oleh Pemerintah Indonesia di beberapa desa terpencil disinyalir belum berhasil mempersempit kesenjangan digital. Untuk mencari solusi, diperlukan gambaran mengenai gap yang menyebabkan permasalahan tersebut. Oleh karena itu, penelitian ini dilakukan dengan tujuan untuk menggambarkan upaya-upaya yang telah dilakukan oleh pemerintah di Indonesia, dan umpan balik masyarakat dalam hal adopsi internet. Data diperoleh dari pengamatan dan diskusi dengan pejabat pemerintah dan masyarakat beberapa desa rural di Indonesia Timur yang dipilih secara purposive. Data dianalisis secara kualitatif menggunakan sudut pandang difusi inovasi. Penelitian ini menghasilkan gambaran bahwa program pemerintah tersebut belum disambut dengan antusias oleh masyarakat, berbeda dengan layanan komersil, jaringan broadband seluler, yang sebenarnya tidak gratis. Fasilitas tersebut malah lebih disukai karena unggul dalam semua fase difusi inovasi. Akan tetapi, broadband seluler komersial tidak tersedia secara merata, terutama di daerah dengan minim populasi. Selain itu, ditemukan bahwa upaya pemerintah daerah dalam membangun akses komunikasi masyarakat tidak sama kuatnya.
\end{abstract}

Kata kunci: adopsi internet, komunikasi, masyarakat terpencil, pembangunan rural. 


\section{INTRODUCTION}

Every individual citizen has an equal right in getting services from the government (Smith \& Wales, 2000). The Government of Indonesia has continued to strive for equitable development, although there are still many areas that have not been successfully addressed (Winanti \& Purwadi, 2018), particularly in eastern Indonesia (Amalia, 2012).

In the field of communication, which is considered as an enabling factor of the pace of development acceleration (Laouris \& Laouri, 2008), the Ministry of Communication and Information Technology is mandated to narrow the digital divide and create an Indonesian information society. Since the internet is considered as the icon of the ICT, the government attempts to make the whole community familiar with it. It has also been reported that the inadequate of ICT infrastructure, expensive service prices, the large number of middle-down society and the lack of a government role in equalizing and popularizing Information and Communication Technology (ICT) (Hadiyat, 2014).

For these reasons, programs of providing free integrated communication and informatics facilities have been carried out, especially in remote villages. Unfortunately, programs those have been rolled out for two decades have not shown optimal results (Ginting, 2017) due to the policy makers suspected of being more focused on technological aspects and less considering the socio-cultural one (Wahyono, 2011). Whereas in order for the efforts to be effective, then before determining a policy, one should understand the complex relationship between technology and development (Laouris \& Laouri, 2008), including the characteristics of policy recipients (Smith, 1973).

However, to achieve the goal, the government must be persistent and mature in its commitment, although the success of the government's efforts remains dependent on the society, whether they want to adopt the technology offered or not.

The solution which is worth trying is the provision of broadband networks. Phillip et al., stated that infrastructure imbalance between UK areas has to increase entrenched urban-rural divide (Philip et al., 2017). Prieger has also reported that the availability of broadband networks, even the rural areas got lower quality, has still reduced the digital divide in the US (Prieger, 2013). Mobile broadband has a significant effect on development, especially for low-income countries (Thompson \& Garbacz, 2011).

Base on previous reasons, especially the bad experience that Ginting (2017) shows, then the current research aims to compare the adoption of internet by the society through free internet service held by the government through Integrated Broadband Village (IBV) and Commercial Mobile Broadband (CMB) by commercial companies in remote areas of Indonesia. I assume may short of CMB be sollution to the internet penetration effort to the society.

Previously, some scholars who have researched adoption of internet in rural America using diffusion of innovations through contemporary perspective and cognitive theory suggested connecting potential users with previous broadband users to emphasize benefits of broadband use (LaRose et al., 2007). Scholars who researched on internet-based communication telecentres, recommended the integration of intelligent software to be applied, so that the wool farmers in Africa might get the best information and solutions when facing problems (Dlodlo, Hunter \& Cele, 2008).

Research on digital divides and mobile internet in Indonesia has resulted that Indonesian prefer to use mobile devices (Puspitasari \& Ishii, 2016). Craftsmen and businessmen in a Java-rural area with Commercial Mobile Broadband 
(CMB) facilities have utilized the internet, even though it was still considered as a very low utilization (Waluyo, 2010). The researchers who studied digital inequality across rural, suburban, and urban counties found the remote communities were slow in diffusing the internet technology (Stern, Adams \& Elsasser, 2009). This research was conducted with the aim of illustrating the action of Indonesian government has made in term of narrowing down the digital divide, and how the community adopt the internet.

\section{CONCEPTS}

In this current research, internet broadband is defined as a global system of an interconnected computer with a high capacity transmission technique using a wide range frequency which enables a large number of messages to be communicated simultaneously (Colombo, Croce \& Grilli, 2013). Free integrated broadband facilities are government subsidies in the form of sets of internet devices those are intended for free use by the public (Dhahir, 2018). Commercial mobile broadband is a paid signal of internet broadband service that is provided by a commercial company and needs a particular device to access (Middleton \& Bryne, 2011). Remote communities are residents of areas those often have a small population size, older demographic structure, population decline, economic specialization, and geographic isolation or are far from urban areas (Slack, Bourne \& Gertler, 2003). People would be seen their income monthly, if it below IDR1,000,000 they would be defined as poormen, if it between IDR1,000,000 to IDR3,000,000 they would be defined as midler economy class, and if it above IDR3,000,000 they will be defined as richmen. The definition would also be based on the observation to their houses condition. If it permanent and decent, then one defined as middle-upper, and vice versa.
The internet diffusion referred to in this study is the process of internet adoption by society referring to the diffusion of innovation model proposed by Rogers. He focuses on four things, namely: individual character (socioeconomic, communication habits, attitudes, and skills), technology adoption (adopt or reject), technology utilization (frequency and variation), and social impact (productivity, level of information). $\mathrm{He}$ stated that the adoption of innovation is determined by five phases, namely: knowledge, persuasion, decision, implementation and confirmation (Rogers, 1983, 2002), then Cangara (2015) groups these phases into 3 parts, namely the antecedent, the process, and the consequences.

The antecedent part is strongly influenced by individual characters of the audience. The process stage consists of knowledge, judgment, and decisions. Learning about the social system will motivate audiences to proceed to the next process when innovation which is considered as a new item, in harmony with the previously adopted social system, and vice versa.

The next part will be a consideration for judgement stage, when the audience begins to question what relative advantages are gained by adopting the innovation, and whether compatible, uncomplicated, testable and observable. Relative advantage is the degree to which an innovation is considered to be better or superior than ever before. This can be measured in several aspects, such as economic aspects, social prestige, comfort, satisfaction, etc. Compatibility is the degree to which the innovation is considered consistent with prevailing values, past experience and the needs of the potential adopters. The complexity of an innovation to be understood and used determines whether it will be adopted or not. Trialability is the degree to which an innovation can be tested within a certain limit that aimed at reducing uncertainty 
toward the innovation. Observability is the level of ease of observing the results of an innovation. The greater the relative advantage felt by adopters, the more compatible the innovation is, the less its complexity, the higher level of its trialability and observability, the easier it will be adopted (Cangara, 2015).

After considering, the audience will make a decision to adopt or reject the innovation. After that, it is the consequence part, which if expectations match reality or better, the adopters will continue to adopt and/or replace with similar innovations those benefits are the same, but vice versa, they will stop adopting. The rejecters will continue to refuse if they see the adopters fail to reach benefits according to their standard, on the contrary, it is likely that they will adopt it if they consider the adopters to benefit (Cangara, 2015; Rogers, 2002).

\section{RESEARCH METHODS}

This research uses a qualitative method. Data were obtained from observations and discussions with the government officials and society in several purposive selected rural villages in Eastern Indonesia. The eastern Indonesia region is more suitable to be the source of data of this research, due to its level of the deterioration nature which is more severe than the western Indonesian region (Amalia, 2012).

The selected villages were Kampung Unipo and Wiraska-Papua, Lutharato-East Nusa Tenggara, Olilit Raya-Maluku, and Mattiro Ujung-South Sulawesi in the period 2012-2018, as well as literature reviews. Kampung Unipo and Mattiro Ujung were selected because both had a small population size, older demographic structure, and were far from urban areas, as well as there is no IBV and CMB in these both villages. Wiraska was selected because it was an outskirt which had an economic specialization, and CMBs.
Lutharato was selected because it had a small population size, older demographic structure, economic specialization, geographic isolation and IBV. Olilit Raya was selected because it was far from urban areas and has both IBV and CMB.

All selected villages could be defined as a remote area, because they have at least one character that remote society has, as Slack, Bourne, \& Gertler (2003) defined. They varied in terms of IBV and CMB availability. There were two villages did not had those both facilities, and each one village had only IBV, only CMB as well as had both. The current research aimed to determine in which stages internet (via IBV and/or CMB) was adopted by the remote societies. Villages without any internet facilities were also selected because there was a probability that they had been informed about it, so it became possible that they in process of adopting the technology.

Observation is done in order that the natural conditions of the object of the research can be revealed (Sugiyono, 2010), while interviews and discussions were conducted to determine deeper into things that have been observed or haven't those the informant may know. There are minimum 32 informant were selected randomly in rural (far from the village center) and urban (around the village center) areas. The certain number of information is aimed to get wider and quantifiable data. The stratified-urbanrural classification area was aimed that a village is truly represented.

The analysis of the research is following Miles and Huberman's interactive model (Gunawan, 2013). After data collected, filtered and classified, then the research displays the descriptions of the society's geography, topography, internet service availability, demography, perceptions, and expectations on the internet, as well as their experience in relationship with it. The connections among these matters to be explored. 


\section{RESULTS AND DISCUSSIONS}

\section{Kampung Unipo, Siriwo District, Nabire Regency, Papua Province}

Base on observation and interview to 32 natives and 3 migrants that was conducted in July 2018, found that Kampung Unipo is a village located one hundred kilometers south of the city center of Nabire which takes a minimum of two hours road trip. Previously it takes a minimum of one day, said Mr. Jona, a native who ever went to school in Nabire City. It is on the route to other districts in Papua. This area is one mainland with Jayapura, the provincial capital with a land distance of 850 kilometers. It is called 'inland' by urban people. The village, which is a mountainous region and river, has just been recently facilitated with electricity service in 2017 . When observed in July 2018, there is no mobile broadband signal here, whether from IBV or CMB.

From the approximately nine hundreds of population (BPS Kabupaten Nabire, 2018), the majority could be classified as living below the poverty line since houses were very poor of facilities, their income below IDR500,000 per month and they acknowledge their selves as so. The people who inhabit this place that I could meet were mostly Papuan natives who live according to local customs and work as farmers, but the more famous icon of this area is the cross-district traveler's haven, in the form of food stalls owned by migrants from Sulawesi and Java.

From the interview data, it was found that indigenous people did not have internet equipment, except two people of them, Mr. Jona and Ms. Fransiska Iyai who were 19 and 20 years old. Some indigenous people, Mr. Marten Degei, Mr. Melkion Giai, Mr. Yakoba Butu, and Mrs. Margareta Iyai, said that they did not need a cell phone, therefore they were not interested in it. They did not perceive the internet as their need.

Mr. Jona and Ms. Fransiska explained that indigenous people who had had cellphones like them, whether the $2 \mathrm{Gs}$ or the smartphones, bought it at the city when they lived in the city for work or school. Both informant said that they began to learn to operate the devices by trying to run the device owned by their relatives, even if they never went to the city. According to 3 informant who were migrants, Ms. Sofie Pangantong, Mr. Subandi, and Mr. Zakaria, the average migrants had a cellphone, whether $2 \mathrm{G}$ or smartphone and so did they. They said that they had been using it in areas where the signal was available. Their activities which supply goods from the city were required to have the equipment. They admitted that they use it to stay connected with family. Whereever and whenever the signal was not available, both indigenous people and the migrants admitted that they used the cellphone for entertainment or just keeping it. These cellphones users hope that the internet mobile broadband services will be provided in their areas, since they had already known on how to use the internet. They perceived the internet as their needs.

\section{Olilit Raya, South Tanimbar District, West-Southeast Maluku Regency, Maluku Province}

Base on observation and interviews to 32 people those were conducted in June 2017, found that Olilit is part of the regency city center. This area is generally a plain with little hills. It is located six hundred kilometers away, separated by the Banda Sea in southeast Ambon, the provincial capital. The population of about six thousand (BPS Kabupaten Maluku Tenggara Barat, 2018) is a mix between indigenous and migrant, indigenous and migrant. They work as fishermen, traders, employees and traditional fabric weavers. Most of the community could not be defined as poor, due to 30 from 32 informants said that their income above IDR3,000,000 per month, while 2 said above IDR2,000,000. 
Mobile broadband is available in this region. Starting with the local government's initiative at 2005 to cooperate with cellular service providers. At that time, the government approached the company to invest by opening mobile telecommunications services in the region. It is why, not long from the spread of $3 \mathrm{G}$ and $4 \mathrm{G}$ technology in major cities in Indonesia, the Olilit villagers have also been enjoying it.

Communities, especially the younger generation generally have mobile phones, either the $2 \mathrm{Gs}$ or smartphones. They claim that ICTs are very useful for them, especially to communicate, find information and exist on social media, $\mathrm{Mr}$. Asriadi and Mr. Robert, also students, explained that. They told that they began to learn to operate the devices from their friends who have it more previously.

In 2015, this village was one of the recipients of the Integrated Broadband Village (IBV) program, the provision of free communication and informatics Ministry of Communication and Information Technology. Unfortunately, the Headman, Mr. Corneles Fanumby at June 2017 reported that the users were still under one percent, even though he had socialized it to the general public and schools.

Several informants who were high school students (Mr. Asriadi and Mr. Robert), civil servants (Mr. Satya and Mr. Cornelius), and traders (Mrs. Murni and Mrs. Maria) said that accessing the internet via cellphones was more enjoyable than through IBV, because it was more private and more flexible in terms of time and place, even though internet access with a telephone is not free. In addition, they also claimed that the socialization carried out by the management of IBV was lacking in their understanding. Strangely, when asked if the facilities were withdrawn or relocated to another region, they refused. They reasoned the facilities might be useful for those who have no personal ICT equipment.
This village was equipped with IBV dan CMB, but the community (32 informant, including the Headmen) preferred to use CMB. This choice was acknowledged even by those who had not had ICT device. Even the headmen acknowledged that he preferred the utilization of IBV, but I saw him playing with his smartphone when interviewed.

\section{Lutharato, South Lamaknen District, Belu Regency, Province East Nusa Tenggara}

Base on observation and interviews to 32 people those were conducted in July 2016, found that Lutharato is located to the east of Kupang, the provincial capital, with a land distance of about three hundred kilometers, or an air distance of two hundred kilometers. It borders Timor Leste. It is a mountainous region. Only a portion of the area had electricity and there were no mobile broadband signals here.

Of the approximately one thousand inhabitants (BPS Kabupaten Belu, 2018), most of them still live below the poverty line, due to 26 of 32 informed acknowledged that their household's income was only below IDR1,000,000; five were below IDR2,000,000 and only 1 was above IDR3,000,000. Base on the observation and interview with the headman, Mr. Agustinus Bere, the society were mostly indigenous people who live according to local customs and work as farmers, and traditional cloth weavers.

Most of 32 informant had not used cellphones. Only 3 of them had the ICT devices. They it was because of the lack of adequate network facilities. Some people, like Mr. Alfons Karaen and Mr. Agustinus Bere, and Mr. Stevanus whose daily activities in the regency center or ever live there have the $2 \mathrm{Gs}$ cellphones and/or smartphones. They admitted that they recognize the technology from the visitors who came to Lutharato and/or their friends who lived in urban areas. They hope telecommunication networks, including broadband internet networks to be 
available in their region, because they knew that cellphones are able to fulfill their daily communication needs.

When interviewed in July 2016, Mr. Alfons Karaen explained that in 2015, this village received the IBV program and he was assigned as Pandu Desa (manager of IBV). Unfortunately, he reported that the users of the facility were still very minimal, and even then, dominated by migrants, not native villagers, even though he had made various efforts in order that the community used it. When interviewed, found that there were only five of them whoever come to utilize the IBV, such as: Mr. Stevanus, Ms. Christina, Mr. Misel, Mr. Joan, and Mr. Willem. The first four mentioned ones acknowledged that they had previously familiar with "warnet" (rental integrated internet devices services) and had no other choice for accessing the internet from the village except the IBV, while the last one used to follow his friend going to the IBV. When confirmed why they did not use IBV, 10 informant from the community members reasoned that they were not familiar with the facility, and did not understand how it works so then it brought benefits.

On the contrary, all of 32 informant refused if the facilities were withdrawn, because they were proud of having IBV in their village. For example, when asked "is it better the IBV to be moved to where it is needed more?", Mr. Robert who actually never used IBV said "Of course not! Hasn't it been used by several people? After all, We are proud of the government project here, because some people from other villages who do not have the facility become often visiting this village".

\section{Wiraska, Wanggar District, Nabire Regency, Papua Province}

Base on observation and interview with 32 people that was conducted in July 2018, found that wiraska is a village located twenty kilometers west of the city center of Nabire. This village is adjacent to the transmigration area. This village tends to be in the form of a plain. The mobile telecommunications network has been able accessed since more than ten years ago from this area. Technological advancements such as the $3 \mathrm{G}$ and the $4 \mathrm{G}$ enter this area almost simultaneously with major cities in Indonesia, although they claim that network quality is relatively poor.

When interviewed, Mr. Ponimin, the headman, told that the majority of the two thousand two hundred inhabitants (BPS Kabupaten Nabire, 2018) were a mix between indigenous Papuans and migrants from Java who had participated in the governmental transmigration program since thirty years ago. Base on their acknowledgment of their household's income per month, they were still classified as living below the poverty line, due to 29 of 32 of informant acknowledge that their household's income are maximum IDR1,000,000 per month while 3 of them had income amount more than IDR3,000,000. But, according to the observation, their houses were permanent decent houses, so in fact they could also be defined as middle to upper class. When interviewed, some of them acknowledged that they are active of being farmer (25), trader (3), and employees (4), either in the village or at the city center.

Base on the observation found that many of the society has utilized mobile phones, both the $2 \mathrm{Gs}$ and/or smartphones. There were 14 of 32 informant utilized 2Gs phones, 10 utilized smartphones, 5 informant utilized both devices and the rest (3) have no device. When asked about ICT, they saw that ICT has benefits. An informant, Irian Wonda told that the example of ICT utilization they did was 'traditional online bike taxi'. The customer orders via SMS or phone call to be picked up or delivered. Besides, those 15 informant who utilize smartphone admitted that they utilized that for social media and communications with family and relations. The informant really hope for the quality of communication signal 
services, including the internet to be improved.

\section{Mattiro Ujung, Luikang Tupabbiring District, Pangkep Regency, South Sulawesi Province}

Base on observation and interviews to 32 people those were conducted in May 2017, found that Mattiro Ujung is in a small island which is located about seventy kilometers west of the city of Pangkajene, the regency capital, and Makassar, the provincial capital. Electricity needs are filled with electricity generators. Broadband signals are not detected on this island, except when sometimes a large ship is passing. The Headman, Mr. Hasanuddin Kuna told that majority of the population of about one thousand and five hundred people (BPS Kabupaten Pangkajene Kepulauan, 2018) are fishermen. It has received service from the central government, in the form of ships equipped with fish detectors. According to officials in the district center, Mr. Idham, this was less effective, because only a few people enjoyed it due to the limited knowledge and authority.

Even if they consider cellphone as useful, especially for communication, most of them have not had a cellphone, but some people are vice versa. There were only two informant (Mr. Hasanuddin Kuna and Mr. Zainuddin) had smartphones, and two (Mr. Syamsuddin and Mr. Rahmat) had 2Gs. Therefore, both the villagers and local government are looking forward to mobile broadband services in their area. Mr. Syamsuddin told that he knew about the cellphone from visitors, relatives, and friends who have ever gone or lived in the city for working, going to school and other activities.

According to a local government official Mr. Idham, if the common communication network service is held in the area, then the user will be wider than IBV due to its wide range. He stated that he was traumatized by a similar IBV program that was implemented in other regions of the district, where in addition to the community not enthusiastic about using it, it was also required operational costs to run, even though those were not always granted in the budgeting proposal. Those programs only become a burden that does not appear to have an advantage. So far, the local government has only been able to build up the telecommunications infrastructure little by little but has not able to establish the connection, because of constrained costs.

The Indonesian government has attempted to synergize various stakeholders in order to realize an information society. Several policies in the field of communication and information technology have been dissected from several countries, so that excellent programs have been formed, namely: increased e-literacy, equitable infrastructure development, ICT industry facilitation, information dissemination, and public service interoperability (Latisuro, 2013).

Unfortunately, equal distribution of infrastructure as an effort to open up the communication access of remote community in order that they are not further left behind by the urban community has not been welcomed enthusiastically. IBVs those have been provided for them have not been used optimally. They admitted that they prefer to use CMBs which were actually paid. Even those who were still living under the poverty line have also shared the same opinion.

In the diffusion model of innovation point of view, the comparison between free-IBV versus Commercial Mobile Broadband $(\mathrm{CMB})$ in remote areas of Indonesia will be as follows.

\section{The Antecedent Part}

Socio-economic conditions in most remote rural communities in Indonesia, which are mostly considered to be below the poverty line, who live in the plains of land, mountains, or the shores of islands have a survival mechanism that is 
dependent on and satisfied by natural products (Dharmawan, 2007). This makes some of them feel no problem in life without the latest technology, including ICT, like people in Kampung Unipo.

Some tribes have a habit of colony living, while others have a wander culture leaving their hometown (Salazar, 2016). In Papua and Nusa Tenggara, it is very common to find areas with dominant inhabitants having clans from the same tribe. They usually have their own language to communicate. They feel more comfortable communicating with fellow tribes, rather than with outsiders who have different cultures, although they actually do not reject outsiders, but only more comfortable with their fellow tribes or relatives, as Mr. Jona and Ms. Fransiska from kampung Unipo, Mr. Asriadi and Mr. Robert, form Olilit Raya, Alfons Karaen and $\mathrm{Mr}$. Robert form Lutharato, and $\mathrm{Mr}$. Syamsuddin from Mattiro Ujung said. The situation is in line with social penetration theory, which self-disclosure will be easier in a more intimate stage (West \& Turner, 2008). Nowadays, however, it is not a few of their group members have wandered into the city and occasionally go home and bring gifts in form of material and urban culture. Sometimes the villager was impressed with what is brought to them and sometimes were confused about the weirdness of the city man. So is in other population, such as Sulawesi, and Maluku, who has already familiar with the wandering culture. When any family member is wandering, they feel they miss him. For those who are familiar with ICT, then they really hope to use it to remedy for their longing. Both IBV and CMB can be used as a remedy for their longing. The difference is, IBV is carried by foreigners, while CMB is introduced by their relatives.

Basically, both types of facilities are considered as good by the community. It's just that various limitations, including limited knowledge will differentiate the level of adoption. For those who are just getting to know, the confidence to try and learn using a tool that belongs to someone else is different from that of relatives. There is a feeling of worry about damaging someone else's property. It seems that suggestion to connect potential users with relatives who were previous internet users to emphasize the benefits of internet use (LaRose et al., 2007) might works.

At the antecedent part, although both have not been perceived as basic needs, socio-economically the adoption process of IBV should be more preferred than CMB, because in order to obtain IBV services, one does not need to pay expenses such as $\mathrm{CMB}$ which requires someone to have a device and credit, except time and energy to come to IBV. On the contrary, in terms of their communication habits which were more priority to relatives making the innovations brought by outsiders do not have a greater chance of being adopted. Moreover, they have not really known what the benefits of the innovation offered, besides that they do not have the skills to operate it. In this case, actually CMB is preferred. Telecenter that was suggested (Dlodlo, Hunter \& Cele, 2008), seemed not working well in Indonesia.

\section{The Process Part}

Phases in the adoption process part begin with the introduction and matching process of the innovation with the social system norms, tolerance of deviance, and communication integration. In general, ICT does not violate customary norms adopted by the community. Unfortunately, IBVs have not been communicated integrally to the community. Even though the management claimed to conduct socialization, the community told that they felt that they did not get a clear description of it. This continues to the lack of material to persuade people to adopt IBV as an innovation. The requirements needed for people to consider adopting or rejecting an innovation depends on the relative advantage, the compatibility, the complexity, the trialability, and the observability. 
In terms of relative advantages, some indigenous people in the inland of Papua still do not consider the internet is useful for their lives. Therefore, other elements in the process part are not of interest to them. On the contrary, for a view of them who have seen the relative advantage got by the urban people who are able to communicate remotely and indefinitely, and can enjoy entertainment using mobile ICT devices, they finally gradually adopt the technology. Residents of other remote areas those have been reached by internet facilities, both IBV and CMB generally consider them as good things.

In terms of the compatibilities, the society generally does not consider the ICT is contradictive with the prevailing values, past experience and the needs, but CMB is indeed more desirable, even if paid, because the character of mobility, privacy and familiarity of $\mathrm{CMB}$ is higher than IBV's. For some villagers, such as in Olilit Raya and Lutharato, IBV is considered more complicated compared to $\mathrm{CMB}$. It requires time for going to IBV. In addition, if there were things they did not understand about how to operate the devices those available at IBV, they should ask Pandu Desa.

The character of Indonesian that is polite, sometimes makes them shy to ask. Moreover, they also afraid of damaging the public property assets, then they doe not dare to fiddle with the devices. Unlike IBV, CMB is less complex and more trialable. $\mathrm{CMB}$ can be accessed everywhere using compatible devices. In addition, if there are things that have not been understood, the users can tamper with their devices, or at least they can ask the person who lent them the device, the person they have known well, their acquaintance.

CMB has been used widely, so it is more observable than IBV. Even non-user communities in the remote areas with minimal infrastructure are already informed by the progress of ICT through the urban people they met or visited them.
Of all aspects of the adoption process, CMB is better supported than IBV, except for costs.

\section{The Consequences Part}

The statement of several informant form Olilit Raya, a village with IBV and $\mathrm{CMB}$, who were high school students, civil servants, and traders that accessing the internet via cellphones was more enjoyable than through IBV, because it was more private and more flexible in terms of time and place, even though internet access with a telephone is not free, could be understood that after trying both services their selves or knowing someone else do adopt, both adopters and rejecters might insist on their attitude, or change instead. It depends on the perceived social impact.

IBV is still strange for some of the society, as 10 informant from Lutharato told that they were not familiar with the facility, and did not understand how it works so then it brought benefits, so they do not come to utilize it. On the contrary, $\mathrm{CMB}$ is very popular and many people have enjoyed it, especially people who want to stay connected with relatives and relations and have experience using $\mathrm{CMB}$ previously. It has been proven that they continue to use it. Some migrants are existing adopters who continue to use ICT tools because they have gone through the stages of the process, and consider them able to meet their needs. In another hand, those who have not used it, are expecting to have the service due to their consideration that its value for them. It is in line with the previous research (Puspitasari \& Ishii, 2016).

\section{The Availability of Internet Facilities}

Data from 5 villages with the different availability of IBV and CMB, which were: a village with IBV only, another village with $\mathrm{CMB}$ only, another more with both IBV and $\mathrm{CMB}$, and two other villages without $\mathrm{CMB}$ neither IBV, show that $\mathrm{CMB}$ is still more expected. Favorites of $\mathrm{CMB}$ has not been influenced 
by its availability. The reason that cause of this circumstance is information.

Information about $\mathrm{CMB}$ is more massively spread in every level of society than IBV. It is why, even in the areas without both services, like in Kampung Unipo and Mattiro Ujung, or where there is only IBV as internet facility, like in Lutharatho, CMB is just more favorite. A few of them use IBV because of no choice. The nomads who come back from urban areas bring information about $\mathrm{CMB}$ to their villages, so do the visitors who visit them. At the same time, the users in villages those have both kinds of service, like Olilit Raya, compare the feature of each services and proofed that $\mathrm{CMB}$ was more enjoyable. Furthermore the society those have been facilitated with $\mathrm{CMB}$, of course, they favor it.

\section{The Income Level of the Society}

The low income of the society does not become a barrier for people to buy devices for accessing the internet through the CMB. The IBV is free, but for reasons of convenience that are unequal between both services, people ignored IBV and choose CMB. They seem to be loyal to CMB because recognize it early than IBV, and they have felt comfortable with it. This circumtance is similar to internet customer loyalty to an internet service provider that found by (Chiou, 2004). Indeed for the sake of convenience and comfort, people sometimes prefer the things those had to be paid rather than the free but difficult and uncomfortable, like what Anderson \& Thornley (2014) has found when researching the national health service.

\section{The Government's Policy}

The central government has tried to penetrate the internet to remote communities, with various IBV programs, both mobile and immobile. However, internet penetration has not been evenly distributed to all regions due to the vastness of Indonesia. Unfortunately, people who have been provided such facilities are still lacking in adoption.

Meanwhile, among local governments do not have the same efforts in penetrating the internet. In some areas that have not been or have just been reached by electricity, the problem of communication networks has not become a concern of local government. Even if an area has been electrified, a telecommunications company that provides CMB does not necessarily have the interest to build a CMB in the region if the population is small, because it can cause losses to the company's business. Other local governments actually have the spirit to penetrate the internet in the midst of society but are often constrained by costs. However, there are still local governments who persistently lobby private companies to open networks in their regions, such as the local government of West-Southeast Maluku Regency.

\section{CLOSURE}

\section{Conclusion}

In terms of geography and topography, Indonesian regions have almost the similar character. There are remote areas inland with the capital the middle of the land, and some are in islands which are far apart by the ocean. Unfortunately, the development is not necessarily the same.

The community provided with IBV by the government turned out to be less adopting. In the antecedent part, people only understand that IBV is a good thing and does not conflict with the values they profess, it's just that they do not know clearly what kindness is. They are more familiar with CMB which has been more widely used by urban communities, than with IBV. In the process part, the public considers $\mathrm{CMB}$ to be greater at a relative advantage, more compatible, less complex, more trial able and more observable than IBV too. In the consequences part, 
existing users still use $\mathrm{CMB}$ and even though some of them have immigrated to an area without services, they still consider that $\mathrm{CMB}$ is useful. People who see the usefulness of CMB also expect to enjoy it. Meanwhile, there are no IBV users who have been successful in the consideration of the public with these tools.

This may occur because of the government efforts that are not equal, or of the reluctance of telecommunications companies to invest in areas with little population or predicted not to develop. It is recommended the disadvantaged regional governments to imitate the steps of the other governments those have similar characteristics and have succeeded in their efforts of narrowing the digital divide.

Besides, if the private sectors are not willing to take part in development as a moral responsibility, then rather than the government investing with such IBV which were not accepted with enthusiasm by the community, I recommend the government subsidize remote areas so that they can enjoy broadband network. Another recommendation that can be suggested is the provision of free IBV facilities, but with the same character as CMB in terms of mobility, convenience, trialability, etc. In short, I also recommend the procurement of a free version of CMB.

\section{Recommendation}

The current research is limited to empirical data which was discussed using a qualitative approach. Besides, the coverage was only in a small part of eastern Indonesia. Future research might be open for quantitative and/or experimental analysis with a wider area.

\section{REFERENCES}

Amalia, F. (2012) PENGARUH PENDIDIKAN, PENGANGGURAN DAN INFLASI TERHADAP TINGKAT KEMISKINAN DI KAWASAN TIMUR INDONESIA (KTI) PERIODE 2001-
2010. Econosains Jurnal Online Ekonomi dan Pendidikan. [Online] 10 (2), 158169. Available from: doi:10.21009/econosains.0102.02.

Anderson, C. \& Thornley, T. (2014) "It's easier in pharmacy": why some patients prefer to pay for flu jabs rather than use the National Health Service. BMC Health Services Research. [Online] 14 (1), 35. Available from: doi:10.1186/1472-696314-35.

BPS Kabupaten Belu (2018) Lamaknen Selatan Dalam Angka 2017. Atambua, BPS Kabupaten Belu.

BPS Kabupaten Maluku Tenggara Barat (2018) Kecamatan Tanimbar Selatan Dalam Angka 2017. Saumlaki, Badan Pusat Statistik Kabupaten Maluku Tenggara Barat.

BPS Kabupaten Nabire (2018) Distrik Wanggar dalam Angka 2017. Nabire, BPS Kabupaten Nabire.

BPS Kabupaten Pangkajene Kepulauan (2018) Kecamatan Liukang Tupabbiring Dalam Angka 2017. BPS Kabupaten Pangkajene Kepulauan.

Cangara, H. (2015) Edisi Revisi Perencanaan \& Strategi Komunikasi. Jakarta, Rajawali Pers.

Chiou, J.-S. (2004) The antecedents of consumers' loyalty toward Internet Service Providers. Information \& Management. [Online] 41 (6), 685-695. Available from: doi:10.1016/j.im.2003.08.006.

Colombo, M.G., Croce, A. \& Grilli, L. (2013) ICT services and small businesses' productivity gains: An analysis of the adoption of broadband Internet technology. Information Economics and Policy. [Online] 25 (3), 171-189. Available from: doi:10.1016/j.infoecopol.2012.11.001.

Dhahir, D.F. (2018) Pemanfaatan Program Desa Broadband Terpadu oleh Masyarakat Desa Lutharato. Jurnal Pikom (Penelitian Komunikasi dan Pembangunan). 19 (No. 2), 73-84.

Dharmawan, A.H. (2007) Sistem Penghidupan dan Nafkah Pedesaan: Pandangan Sosiologi Nafkah (Livelihood Sociology) Mazhab Barat dan Mazhab Bogor. Sodality: Jurnal Sosiologi Pedesaan. [Online] 1 (2), 169-192. Available from: doi:10.22500/sodality.v1i2.5932. 
Dlodlo, N., Hunter, L. \& Cele, C. (2008) A KNOWLEDGE-BASED SYSTEM TO TRAIN THE SOUTH AFRICAN RURAL FARMERS THROUGH A VSAT-ENABLED INTERNET SERVICE. TEXTILE AND APPAREL. [Online] 18 (2), 159-164. Available from:

http://dergipark.gov.tr/tekstilvekonfeksiy on/issue/23654/251981.

Ginting, M.D. (2017) IMPLEMENTASI DESA BROADBAND TERPADU (Studi pada Enam Desa Penerima Program Desa Broadband Terpadu di Daerah Perbatasan). Jurnal Penelitian Komunikasi dan Pembangunan. [Online] 18 (1), 19. Available from: doi:10.31346/jpkp.v18i1.758.

Gunawan, I. (2013) Metode Penelitian Kualitatif. Jakarta, Bumi Aksara.

Hadiyat, Y.D. (2014) Kesenjangan Digital di Indonesia (Studi Kasus di Kabupaten Wakatobi). Pekommas. [Online] 17 (2), 81-90. Available from: https://jurnal.kominfo.go.id/index.php/pe kommas/article/view/1170203.

Laouris, Y. \& Laouri, R. (2008) Can Information and Mobile Technologies Serve to Close the Economic, Educational, Digital, and Social gaps and Accelerate Development? World Futures. [Online] 64 (4), 254-275. Available from: doi:10.1080/02604020802189534.

LaRose, R., Gregg, J.L., Strover, S., Straubhaar, J., et al. (2007) Closing the rural broadband gap: Promoting adoption of the Internet in rural America. Telecommunications Policy. [Online] 31 (6-7), 359-373. Available from: doi:10.1016/j.telpol.2007.04.004.

Latisuro, S.W. (2013) Kebijakan Strategis Pemerintah Mempercepat Terwujudnya Masyarakat Informasi. Studia Informatika: Jurnal Sistem Informasi. [Online] 6 (2), 16-27. Available from: http://repository.uinjkt.ac.id/dspace/handl e/123456789/31373.

Middleton, C.A. \& Bryne, A. (2011) An exploration of user-generated wireless broadband infrastructures in digital cities. Telematics and Informatics. [Online] 28 (3), 163-175. Available from: doi:10.1016/j.tele.2010.08.003.

Philip, L., Cottrill, C., Farrington, J., Williams, F., et al. (2017) The digital divide:
Patterns, policy and scenarios for connecting the 'final few' in rural communities across Great Britain. Journal of Rural Studies. [Online] 54, 386-398. Available from: doi:10.1016/j.jrurstud.2016.12.002.

Prieger, J.E. (2013) The broadband digital divide and the economic benefits of mobile broadband for rural areas. Telecommunications Policy. [Online] 37 (6-7), 483-502. Available from: doi:10.1016/j.telpol.2012.11.003.

Puspitasari，L. \& Ishii，K. (2016) Digital divides and mobile Internet in Indonesia: Impact of smartphones. Telematics and Informatics. [Online] 33 (2), 472-483. Available from: doi:10.1016/j.tele.2015.11.001.

Rogers, E.M. (2002) Diffusion of preventive innovations. Addictive Behaviors. [Online] 27 (6), 989-993. Available from: doi:10.1016/S03064603(02)00300-3.

Rogers, E.M. (1983) The Innovation-Decision Process. In: Diffusion of Innovations. Fourth Edi. Glencoe, IL, The Free Press. pp. 161-203.

Salazar, N.B. (2016) The (Im)Mobility of Merantau as a Sociocultural Practice in Indonesia. In: Nataša Gregorič Bon; \& Jaka Repič (eds.). Moving Places: Relations, Return and Belonging. Volume 29. New York, Berghahn Books. pp. 2142.

Slack, E., Bourne, L.S. \& Gertler, M.S. (2003) Small, rural, and remote communities: The anatomy of risk. A report prepared for the Panel on the Role of Government.

Smith, G. \& Wales, C. (2000) Citizens' Juries and Deliberative Democracy. Political Studies. [Online] 48 (1), 51-65. Available from: doi:10.1111/1467-9248.00250.

Smith, T.B. (1973) The policy implementation process. Policy Sciences. [Online] 4 (2), 197-209. Available from: doi:10.1007/BF01405732.

Stern, M.J., Adams, A.E. \& Elsasser, S. (2009) Digital Inequality and Place: The Effects of Technological Diffusion on Internet Proficiency and Usage across Rural, Suburban, and Urban Counties. Sociological Inquiry. [Online] 79 (4), 391-417. Available from: doi:10.1111/j.1475-682X.2009.00302.x.

Sugiyono (2010) Metode Penelitian Kuantitatif 
Kualitatif dan R\&D. Bandung, Alfabeta.

Thompson, H.G. \& Garbacz, C. (2011) Economic impacts of mobile versus fixed broadband. Telecommunications Policy. [Online] 35 (11), 999-1009. Available from: doi:10.1016/j.telpol.2011.07.004.

Wahyono, S.B. (2011) Optimalisasi Program Desa Informasi Melalui Penguatan Kelembagaan. Jurnal Penelitian IPTEKKOM. 13 (2), 29-42.

Waluyo, D. (2010) Adopsi dan Pemanfaatan Tik Bagi Pengrajin Keramik dan Gerabah di Kasongan. Masyarakat Telematika Dan Informasi: Jurnal Penelitian Teknologi Informasi dan Komunikasi. [Online] 1 (2), 131-146. Available from: https://mti.kominfo.go.id/index.php/mti/a rticle/view/11.

West, R. \& Turner, L.H. (2008) Pengantar Teori Komunikasi: Analisis dan Aplikasi. 3rd edition. Nana Setyaningsih (ed.). Jakarta, Salemba Humanika.

Winanti, N. \& Purwadi, A. (2018) Study and Design of Distributed Hybrid PVGenerator-Battery System for Communal and Administrative Loadat Sei Bening Village, Sajingan Besar, Indonesia. In: 2018 2nd International Conference on Green Energy and Applications (ICGEA). [Online]. March 2018 IEEE. pp. 129133. Available from: doi:10.1109/ICGEA.2018.8356300. 